\title{
Free, Prior and Informed Consent: Between Legal Ambiguity and Political Agency
}

The principle of free, prior and informed consent (FPIC) is increasingly considered a core element of the international Indigenous rights regime. From its early iteration in the 1989 Convention 169 of the International Labour Organization (ILO) to its more robust articulation in the 2007 United Nations Declaration on the Rights of Indigenous Peoples (UNDRIP), ${ }^{1}$ F PIC has taken on central importance in relations between Indigenous peoples and states, particularly in the context of natural resource governance. However, like other concepts found in fundamental laws such as constitutions or international treaties, FPIC is the product of a negotiated compromise and its sometimes ambiguous wording is subject to different interpretations. To this day theorists and practitioners from around the world, Indigenous and non-Indigenous, continue to debate its precise meaning and implications. ${ }^{2}$ Empirical studies looking at states policies and practices, from Canada and Australia to Latin America, also suggest wide variations in its operationalisation. ${ }^{3}$

1 Convention No. 169 Concerning Indigenous and Tribal People in Independent Countries, 27 June 1989, 1650 UNTS 383; United Nations Declaration on the Rights of Indigenous Peoples, GA Res 61/295, UNGAOR, 61 ${ }^{\text {st }}$ Sess, UN Doc A/REs/61/295 (2007).

2 See for example: M. Barelli, Seeking Justice in International Law: The Significance and Implications of the UN Declaration on the Rights of Indigenous Peoples (Routledge, New York, 2016); C.M. Doyle, Indigenous Peoples, Title to Territory, Rights and Resources: The Transformative Role of Free Prior and Informed Consent (Routledge, New York, 2015); J. Borrows et al., Braiding Legal Orders: Implementing the United Nations Declaration on the Rights of Indigenous Peoples (McGill-Queen's Press, Montreal, 2019); B.L. Gunn, 'Overcoming Obstacles to Implementing the UN Declaration on the Rights of Indigenous Peoples in Canada', 31:1 Windsor Yearbook of Access to Justice (2013) pp. 147-174; D. Leydet, 'The Power to Consent: Indigenous Peoples, States, and Development Projects', 69:3 University of Toronto Law Journal (2019) pp. 371-403.

3 A. Tomaselli and C. Wright, The Prior Consultation of Indigenous Peoples in Latin America: Inside the Implementation Gap (Routledge, New York, 2019); M. Papillon and T. Rodon, 'From Consultation to Consent: The Politics of Indigenous Participatory Rights in Canada', in A. Tomaselli and C. Wright (eds.), The Prior Consultation of Indigenous Peoples in Latin America. 
The lack of conceptual clarity surrounding the notion of Indigenous consent is rightly considered an obstacle to its institutionalisation. As the articles featured in this special issue demonstrate, FPIC's uncertain legal meaning and scope allow for very different interpretations, themselves leading to a broad range of institutional responses. Between definitions of consent as a preferable but not necessarily mandatory outcome of consultation procedures and more substantive/robust conceptions of FPIC as a right to say 'yes' or 'no' to a given project, the gap is significant and the implications very real. Yet, this ambiguity also creates opportunities. Several contributions to this special issue of the International Journal of Minority and Group Rights underscore the agency of Indigenous peoples, not only in challenging restrictive approaches to their participatory rights, but also in giving FPIC a more situated meaning, grounding the principle into their legal traditions and worldviews. ${ }^{4}$

FPIC is therefore best approached less as a legal notion endowed with immanent meaning than as a contested principle that will be given persuasive force (including in the legal field) through its mobilisation as a political resource, most notably by the different actors involved in the governance of natural resources. Such mobilisations, of course, do not operate in a political or institutional vacuum. The capacity of Indigenous and non-Indigenous actors to mobilise FPIC for transformative purposes is bound to be influenced (in both positive and negative ways) by the legal and institutional environment they operate in.

In order to make sense of this complex and highly contingent process, this special issue adopts a multi-disciplinary perspective. The authors come from a variety of disciplines, from law and philosophy to anthropology and

Inside the Implementation Gap (Routledge, New York, 2019); L. Fontana and J. Grugel, 'The Politics of Indigenous Participation through "Free Prior Informed Consent": Reflections from the Bolivian Case', 77:3 World Development (2016) pp. 249-61; A. Schilling-Vacaflor, 'Who Controls the Territory and the Resources? Free, Prior and Informed Consent (FPIC) as a Contested Human Rights Practice in Bolivia', 38:5 Third World Quarterly (2017) pp. 1058-1074; T.G. Falleti and T.N. Riofrancos, 'Endogenous Participation: Strengthening Prior Consultation in Extractive Economies', 70:1 World Politics (2017) pp. 86-121; C. Allard, 'The Rationale for the Duty to Consult Indigenous Peoples: Comparative Reflections from Nordic and Canadian Legal Contexts', 9:1 Arctic Review on Law and Politics (2018) pp. 25-43.

4 See also J. Borrows et al., supra note 3; C. Doyle et al., Free Prior Informed Consent Protocols as Instruments of Autonomy. Laying Foundations for Rights Based Engagement (Infoe, ENIP, 2019), <eprints.mdx.ac.uk/28264/1/Free\%2oPrior\%2oInformed\%2oConsent\%2oProtocols\%20as\%2oInstruments\%20of\%2oAutonomy.pdf>. 
political science. ${ }^{5}$ They each bring their own unique perspective, but also invite conceptual and empirical cross-fertilisation in order to shed light on the potential and limits of the emerging regime of Indigenous participatory rights. While most of the contributions to this special issue draw their insights from the Canadian context, they emphasise normative issues and practical challenges that go well beyond the confines of Canadian laws and institutions. The more explicitly comparative contributions further confirm the many similarities that exist throughout the Americas in debates over FPIC as well as in the challenges that Indigenous peoples face in operationalising the principle.

\section{In Search of Conceptual Clarity}

The ambiguity surrounding the nature, scope and legal interpretation of free, prior and informed consent, as defined in UNDRIP, is addressed head-on in Dwight Newman's contribution. He reminds us that some of the more contentious sections of UNDRIP featuring FPIC can be given very different meanings, depending on the chosen interpretive methodology. A textual approach, which emphasises the specific wording of the Declaration, arguably leads to a somewhat restrictive understanding of FPIC, as an extension of consultation processes. Yet, a purposive reading of the same sections, taking into consideration the overall economy of UNDRIP and its guiding principles, may suggest a more substantive definition of consent as a mandatory requirement. ${ }^{6}$

The fundamental question then becomes: how are we to choose the appropriate legal interpretive methodology? Without taking a firm position on this thorny methodological debate, Newman makes the case for an organic approach, under which the true potential of UNDRIP's more contentious clauses will emerge with time, as other sections of the Declaration are interpreted and given substance. ${ }^{7}$

In his contribution to this special issue, Richard Healey also discusses some of the key conceptual challenges associated with FPIC. One challenge, he

5 The contributions to this special issue were first presented at a two-day workshop in April 2018 at the Université de Montréal, in Canada. We want to thank the participants to the initial workshop, as well as the Centre de recherche interdisciplinaire sur la diversité et la démocratie (CRIDAQ) and the Centre de recherche sur les politiques et le développement social (CPDS) for their support.

6 For slightly different interpretative approaches see Barelli, supra note 3; Doyle, supra note 3.

7 For a diversity of perspectives on UNDRIP interpretation, see J. Hohmann and M. Weller (eds.), The UN Declaration on the Rights of Indigenous Peoples: A Commentary (Oxford University Press, Oxford, 2018). 
argues, is in defining what the act of consenting actually entails. He convincingly argues that the rules and guiding principles associated with individual consent can be extended to the collective level, which leads him to defend a "strong" version of consent as a veto right.

Healey further points to an important distinction between the act of giving consent and the process of decision-making that precedes it. While they are often conflated in discussions over FPIC, he argues that the two operate under distinctive logics and must be conceptually separated. The process of decisionmaking entails the capacity to determine the criteria and principles, as well as the procedure that should be applied to reach a decision on a course of action or a proposed project. The act of consenting (or not), by contrast, is communicative in nature. It involves the granting or withholding of permission to act or to proceed with a project. Healey gives three reasons why the process of coming to a collective decision and consent itself must be kept distinct: first, it avoids any possible confusion between acknowledging an Indigenous right to participate in decision-making procedures about development projects (that may also involve non-Indigenous actors) with the power to consent; secondly, showing that consenting is the act of communicating the 'yes' or 'no' answer of the community makes clear that the process through which the community comes to a collective decision is a matter internal to the group and that it is inappropriate for other actors to seek to intervene in that process; thirdly, and more generally, to understand the power to give or withhold consent in this way allows us to see how consent contributes to a form of "external selfdetermination" for Indigenous peoples, "in the sense that it concerns a right to be free from outside interference".

Avigail Eisenberg also warns us against a reified understanding of FPIC, under which "the allocation of decision-making authority remains with one party only". For Eisenberg, consent should be understood as an extension of Indigenous jurisdictional authority and therefore necessarily involves deeper engagement in the decision-making process, whether it be through shared decision-making or distinct Indigenous processes. Michael Coyle, Martin Papillon and Thierry Rodon as well as Roberta Rice adopt a similar viewpoint in their respective analyses, pointing to the interconnectedness between FPIC and the recognition of Indigenous authority on the land.

\section{$3 \quad$ Institutionalisation and Its Challenges}

Moving from conceptual to more practical considerations, it is clear that the institutional translation of FPIC bears the imprint of its conceptual ambiguity. 
For instance, as underlined by Newman, Eisenberg, Papillon and Rodon, the Canadian government has so far adopted a fairly restrictive interpretation of FPIC that essentially reproduces the wording of some of the more ambiguous sections of UNDRIP. Schilling-Vacaflor and Flemmer's comparative analysis of Indigenous participatory rights in Bolivia, Columbia and Peru point to similar institutional restrictions under regimes more directly influenced by ILO Convention $169 .{ }^{8}$

Schilling-Vacaflor and Flemmer point to significant limits in the participatory regimes that were progressively institutionalised in Latin America. Consultation, they argue, even when the purpose is to achieve FPIC, can be profoundly disempowering for Indigenous groups. These state-driven processes depoliticise opposition to projects, channelling what are often limited resources into tightly controlled and choreographed administrative processes. Indigenous peoples, they argue, can be unwillingly co-opted into such processes without having a real say into the outcome, while at the same time providing legitimacy to the decision to go ahead with the project despite the opposition of those most affected. Eisenberg, as well as Papillon and Rodon, point to similar challenges in Canada, where Indigenous participation in decisions over extractive projects on their lands is channelled through highly regulated impact assessment procedures and the negotiation of benefits sharing agreements with project proponents. ${ }^{9}$

There are of course variations in processes of institutionalisation and some are more successful than others. Roberta Rice reminds us that "institutional arrangements shape political outcomes through the way in which they structure the rules of the game". In her comparative examination of Indigenous rights and resource governance in Ecuador and Yukon (Canada), Rice explains that the institutional mechanisms established in the former in response to Indigenous claims only allowed for a "hybrid regime" falling mid-way between a consultation and a consent regime. In contrast, the process in Yukon could be classified as a "classic consent regime". This is because Yukon's institutional environment includes constitutionally entrenched treaties concluded between the state and the territory's Indigenous communities. These instruments, part and parcel of Canada's fundamental law, provide for de jure and de facto control by Indigenous communities over sub-surface mineral rights. Although

8 See also Tomaselli et al., supra note 4 .

9 For a more detailed discussion of benefits sharing agreements in Canada, see M. Papillon and T. Rodon, 'Proponent-Indigenous Agreements and the Implementation of the Right to Free, Prior, and Informed Consent in Canada', 62:2 Environmental Impact Assessment Review (2017) pp. 216-224. 
Ecuador's Indigenous movement is one of the most active in Latin America, and while such movement led to the inscription in the country's constitution of the right to prior consultation, Rice shows that, in the absence of concrete institutions to translate this principle into practice, like treaties or self-government agreements, Indigenous peoples' territorial rights in Ecuador remain much more theoretical compared to those of their counterparts in Yukon.

Interestingly enough, Schilling-Vacaflor and Flemmer show that in Columbia, Indigenous communities actually fought the adoption of legislation on consultation, fearing that it might dilute the fairly expansive interpretation given by Columbia's "progressive and independent Constitutional Court" to their right to be consulted and accommodated. In other words, a strong judiciary might make it less useful for Indigenous communities to lobby legislatures in the hope of morphing constitutional promises into tangible legislative results. This observation may well hold true for Canada as well, where the Supreme Court's case-law on constitutionally protected "Aboriginal and treaty rights" provides a distinctive, though imperfect, institutional foundation for Indigenous peoples to mobilise in the face of change-resistant federal and, especially, provincial authorities..$^{10}$ Clearly, there is more than one pathway to institutionalisation.

\section{$4 \quad$ Power and Agency}

Papillon and Rodon raise important questions concerning the agency of Indigenous peoples in this process of institutionalisation. While the uncertainty surrounding the actual meaning, scope and operationalisation of FPIC can be profoundly disempowering for Indigenous peoples, they suggest that the

10 The Supreme Court's 'doctrine of Aboriginal rights' has undoubtedly proven, in certain instances, an efficient political lever for Indigenous communities. However, founded as it is on a premise of 'cultural essentialism', the doctrine has been the subject of severe criticisms by both Indigenous and non-Indigenous scholars: R.L. Barsh and J.Y. Henderson, 'The Supreme Court's Van der Peet Trilogy: Naive Imperialism and Ropes of Sand', 42:4 McGill Law Journal (1997) pp. 993-1010; J. Borrows, 'Sovereignty's Alchemy: An Analysis of Delgamuukw v. British Columbia', 37:3 Osgoode Hall L. J. (1998) pp. 537-596; G. Christie, 'A Colonial Reading of Recent Jurisprudence: Sparrow, Delgamuukw and Haida Nation', 23:1 Windsor Yearbook of Access to Justice (2005) pp. 17-54; J. Leclair, "Il faut savoir se méfier des oracles." Regards sur le droit et les autochtones', 41:1 Recherches amérindiennes au Québec (2011) pp. 102-111. 
open-ended nature of the principle can also become an opportunity. By capitalising on the ambiguity of FPIC as defined in UNDRIP, and on the haziness of the duty to consult elaborated by the Supreme Court of Canada, they argue Indigenous communities can actually "challenge the legitimacy of state-driven norms and processes" and develop their own mechanisms to translate FPIC into practice. Papillon and Rodon illustrate this point with two examples of community-driven FPIC processes in Canada: the Cree of Northern Quebec, who have adopted their own mining policy, and the Squamish Nation of British Columbia, who developed a community-based impact assessment process. These are examples of what Papillon and Rodon call strategies of norm appropriation, under which Indigenous peoples fill the so-called institutional void resulting from an ambiguous legal regime and establish their own FPIC processes. ${ }^{11}$

In the same vein, Schilling-Vacaflor and Flemmer also underscore the importance of Indigenous agency in challenging emerging consultation regimes through a diversity of strategies. As they explain, to avoid being simply co-opted in state-sponsored consultation processes, Indigenous communities in Peru, Bolivia and Columbia increasingly seek to "re-politicise" these processes through legal mobilisations, protests as well as more radical forms of refusal, including the boycotting of state-sponsored processes and, like in Canada, the development of alternative mechanisms for affirming their own legal norms and decision-making rules over land and resources management.

Schilling-Vacaflor and Flemmer conclude that the transformative potential of FPIC depends on "the constant pressure, contestation and agency of Indigenous actors and their allies within such processes". The greater the pressure, the greater the chances of ending up with a process in harmony with Indigenous values and interest. Papillon and Rodon come to the very same conclusion when they state that, by engaging in a process of "norm definition through practice", "Indigenous peoples challenge [...] state-centred and instrumental views of FPIC and reaffirm their status as self-determining peoples with the capacity (and legitimacy) to make decisions over the future of their traditional lands."

11 Community-based consultation protocols are another example of norm appropriation, see Doyle et al., supra note 6; J. Leclair, M. Papillon and H. Forget, 'Les protocoles de consultation adoptés unilatéralement par les communautés autochtones au Canada: un modèle de convergence des systèmes juridiques autochtones et étatique?', Recherches amérindiennes au Québec (forthcoming). 
Eisenberg carries the argument a step further. According to her, the conditions of colonial inequality have so distorted the relationship between the state and Indigenous peoples, that obtaining consent is, in itself, not sufficient. In fact, she claims that "organised resistance" is a prerequisite for meaningful consent: "Through organised resistance, communities can develop collective agency, forge political alliances, and re-appropriate their authority over territory and resources that are significant to them. This authority can then be used to shift the terms used to understand land-use conflicts." Resistance, then, would be a means of escaping the limited bounds of state law, and of opening up genuine plural legal avenues. Borrowing from the work of Indigenous legal scholar John Borrows, ${ }^{12}$ Eisenberg claims that, understood in this light, what from one perspective could be qualified as disobedience to state law, can be envisaged as obedience to Indigenous laws. Resistance, therefore, becomes the "enacted" expression of an Indigenous jurisdictional authority over a community's lands and resources.

A Means to an End

FPIC is a conceptual, legal and political minefield, to use Rodriguez-Garavito's analogy. ${ }^{13}$ Not only is the concept itself contested, but its operationalisation is also highly complex, rife with power struggles between competing interests and worldviews. But as several authors in this special issue point out, the battle around FPIC is about much more than the implementation of specific rules, administrative procedures and legislative measures.

For Schilling-Vacaflor and Flemmer, "at the heart of these contestations is the (re-)negotiation of the relationships between States and Indigenous peoples, including the hierarchy between legal norms, questions of resource sovereignty and control [over] territories". They worry that a focus on participatory rights, even when FPIC is nominally the end goal, will postpone more substantive discussions on land authority, jurisdiction and the further institutionalisation of legal pluralism.

Coyle and Eisenberg also warn us against a sort of FPIC fetishism that may lead us to forget the bigger picture. The purpose of UNDRIP, after all, is to create

12 J. Borrows, Freedom and Indigenous Constitutionalism (University of Toronto Press, Toronto, 2016).

13 C. Rodriguez-Garavito, 'Ethnicity.Gov: Global Governance, Indigenous Peoples and the Right to Prior Consultation in Social Minefields,' 18:1 Indiana Journal of Global Legal Studies (2011) pp. 263-305. 
some balance in what has been historically and remains to this day a deeply unequal and unfair relationship between states and the original inhabitants of the land, who were in most cases unwillingly incorporated into colonial regimes. The real test of the Declaration's success lies less in the achievement of successful consultation or consent processes than in the redistribution of power and authority over land, the successful coexistence of a plurality of legal orders and in the cultural, social and economic wellbeing of Indigenous communities. As such, FPIC is more a vehicle than an end result.

Using the Canadian jurisprudence on the duty to consult to make his case, Michael Coyle argues that "focusing solely on the outcome of consultations [and whether or not they produce a legitimate expression of consent] may lead us to overlook the very real significance of the quality of the dialogue that is produced through such interactions and its capacity to advance the longterm relational goals of Indigenous peoples and the state". Coyle points out that a process designed according to the values and legal norms of only one party "is much less likely to produce consensus than one which seeks to find common ground across the two peoples' values and legal orders".

This is certainly not to say that FPIC is a futile goal. After all, the very narrative of consent (or lack thereof) is at the core of the colonial experience. There are good reasons why Indigenous representatives insisted that it figured prominently in UNDRIP, especially in sections discussing land rights and natural resources extraction. ${ }^{14}$ The language of consent is a powerful legal and political resource that directly challenges the assumption of unmitigated state sovereignty that lies at the core of settler-colonialism. However, to be more than an oppositional tool, consent has to be conducive to and constitutive of a different kind of relationship. While none of the authors participating in this special issue carries an Indigenous voice, they point to the importance of making room for Indigenous legal orders, worldviews and approaches to decisionmaking as the way forward in making FPIC a truly transformative instrument. The question of how this can be best achieved can only be tackled in a meaningful way through dialogue with Indigenous scholars and activists.

\author{
Guest Editors \\ Martin Papillon \\ Université de Montréal, Montréal, Canada \\ martin.papillon@umontreal.ca
}

\footnotetext{
14 On the Indigenous rights movement and UND RIP, see S. Lightfoot, Global Indigenous Politics. A Subtle Revolution (Routledge, London, 2016).
} 
Jean Leclair

Université de Montréal, Montréal, Canada

jean.leclair@umontreal.ca

Dominique Leydet

Université du Québec à Montréal, Montréal, Canada

leydet.dominique@uqam.ca 